\title{
Exposure to peat dust: acute effects on lung function and content of bronchoalveolar lavage fluid
}

\author{
Thomas Sandström, Birgitta Kolmodin-Hedman, Maj-Cari Ledin, Leif Bjermer, \\ Sonja Hörnqvist-Bylund, Nils Stjernberg
}

\begin{abstract}
Mechanised production of peat for fuel consumption is associated with high concentrations of organic dust, which is inhaled by the peat workers. In the present study 17 workers at two peat bogs in northern Sweden were examined. Personal sampling of total dust and the respirable fraction was performed during several workshifts. Dynamic spirometry was carried out before and at the end of shifts. Bronchoscopy with bronchoalveolar lavage (BAL) was performed in six subjects at the end of the working season and the results were compared with unexposed reference subjects. Peat workers using modern machines with ventilated cabins containing air filters were found to be exposed to low concentrations of peat dust. The recorded dust concentrations were below the threshold limit value for organic dust ( $5 \mathrm{mg} / \mathrm{m}^{3}$ air) in all but one worker. The respirable fraction of peat dust recorded in the breathing zone of the workers correlated significantly with a decrease in forced expiratory volume in one second $\left(F E V_{1}\right)$. The effect on lung function in nonasthmatic peat workers was, however, small. The concentration of lysozyme positive alveolar macrophages in BAL fluid was significantly lower in the peat workers compared with reference subjects. An inverse correlation was found between the mentioned cells and exposure to the respirable fraction of the peat dust. Furthermore, one particularly dust
\end{abstract}

\footnotetext{
National Institute of Occupational Health, Medical Division, Umeá, Sweden

T Sandström, B Kolmodin-Hedman, M-C Ledin, N Stjernberg

Department of Lung Medicine, University Hospital of Umeá, Sweden

T Sandström, L Bjermer

National Institute of Occupational Health, Technical

Division, Umeả, Sweden

S Hörnqvist-Bylund
}

exposed worker had pronounced increases in alveolar macrophages, fibronectin concentration, and mast cells in BAL fluid.

Peat has long been known to be a fuel for heating. During recent years it has become economically attractive as an alternative energy source and large scale production has been organised in countries such as Ireland, Sweden, Finland, Soviet Russia, the United States, and Canada. The modern methods for harvesting peat produce excessive amounts of organic dust in the air, which is inhaled by the peat workers. Documentation of the biological effects of peat dust has so far been scarce. In a Finnish study dust concentrations of two to five times the threshold limit value (TLV) of $5 \mathrm{mg} / \mathrm{m}^{3}$ air has been reported. ${ }^{1}$ In that study and a follow up $^{2}$ no evidence was found of chronic pulmonary disease or significant impairment of lung function. Cormier and coworkers from Quebec, Canada, did not detect any change in lung function, for peat moss workers as a group, but a high incidence of chronic bronchitis was found. ${ }^{3}$ It has, however, been questioned as to whether the studies had sufficient sensitivity. The sensitivity may have been impaired by the fact that the populations were evaluated as a group without consideration of the fact that absence of lung function deterioration in workers less exposed to dust could have masked effects in more exposed workers. As dust exposure was not recorded with portable equipment in the individual workers, correlations between exposure dose and effects on lung functions could not be assessed. The question of whether peat dust may cause dose dependent impairment of lung function has therefore not been thoroughly studied.

The primary purposes of the present study were to measure the individual exposure to peat dust, to perform multiple lung function tests over time in each subject, and to investigate possible correlations between the dust exposure and lung effects. Because considerable interest has recently been focused on inflammatory lung conditions caused by inhalation of different types of organic dusts, ${ }^{4-6}$ a pilot study on bronchoalveolar effects was included. 


\section{Material and methods}

PEAT SITES AND PEAT HARVESTING

Harvesting of peat is dependent on a dry climate because it is difficult to harvest humid peat. For Scandinavian conditions only June-August is suitable. Young workers, often students, are employed for this seasonal work. As it never gets dark during the summer night in northern Sweden peat harvesting is performed 24 hours a day, which compensates for the short season. Two peat bogs, A (Röjnoret) and B (Träskmyran), were chosen for this investigation. Peat production is heavily mechanised at both sites. At bog A a mainly milled peat production technique is used, whereas at bog B only the more novel sod peat technique is employed. The peat is gradually stripped off the surface by either of the techniques and left to dry for a few days. The milled peat is then harrowed before it is ridged and finally cleared from the fields with pneumatic machines. Sod peat is cleared by movable conveyors. Finally, it is stockpiled with bulldozers. During work the employees sit in ventilated machine cabins. This gives protection against exposure to heat and dust. A minor part of the work is done outside the machine adjusting equipment or clearing stumps that have not been taken away in the preceding grubbing out procedures.

\section{SUBJECTS}

Sixteen men and one woman participated in the investigation. Eleven worked at bog $\mathrm{A}$ and six at bog B. The mean age was 20 , range $17-43$ years. The mean work time with peat production was two seasons (range one to six seasons). Two subjects, one from either bog, had mild bronchial asthma that was treated with inhaled $\beta_{2}$ agonist aerosol when necessary. All subjects worked with peat exclusively during the summer with the exception of a 43 year old smoking supervisor. No one had a history of extrinsic allergic alveolitis (EAA) or organic dust toxic syndrome (ODTS). Six subjects from bog B, including the above mentioned supervisor, were examined with bronchoscopy and BAL. Thirteen healthy, nonsmoking subjects, aged $20-29$, served as a reference source. None of the peat workers or the reference subjects had experienced any airway infection for at least six weeks before bronchoscopy.

\section{DUST MEASUREMENTS}

Portable SKC high flow samplers, model 113, were used for recordings of total and respirable airborne dust concentations in the breathing zone during full workshifts. Sampling of dust was performed by drawing a measured volume of air through a filter by means of the battery powered portable sampler. The weight of the collected material was determined by weighing the filters before and after sampling. Because of the hydroscopic nature of these cellulose filters they were kept in a stictly air conditioned room before weighing. The filters were mounted in plastic holders and placed in the breathing zone of the workers. Cyclones were used for sampling of the respirable part of the dust. The filter for respiratory dust had pores of $8 \mu \mathrm{m}$ diameter. Millipore filters with $0.8 \mu \mathrm{m}$ pores were used for measurements of total dust exposure. The airflow of the pumps was adjusted with a rotameter (Rota $\mathrm{L} 6.3 / 250$ ) to $2.5 \mathrm{l} / \mathrm{min}$ for total dust and $1.9 \mathrm{l} / \mathrm{min}$ for respirable dust measurement. Filters were changed after six to eight hours of sampling. The flow rates were examined when the pumps were changed. Deviations of the air flow greater than $10 \%$ for respirable dust and $20 \%$ for total dust caused the sample to be discarded. The minimal detection amount for dust with this method is $0.1 \mathrm{mg}$.

\section{LUNG FUNCTION}

Spirometry was performed at the bogs with an $\mathrm{OHIO}$ rolling seal dry spirometer. Measurements were made of forced vital capacity (FVC), forced expiratory volume in one second $\left(\mathrm{FEV}_{1}\right)$ and forced expiratory flow at $25-75 \%$ of $\mathrm{FVC}\left(\mathrm{FEF}_{25-75}\right) . \mathrm{Gas}$ distribution and closing volume were recorded with a single breath nitrogen washout method using an OHIO nitrogen analyser 720 , and the alveolar plateau ( $\%$ change $\mathrm{N}_{2} / 1$ ) was calculated. Recordings were taken before and after one of the first workshifts at the beginning of the peat season and at the end of the peat production season. Dynamic spirometry, recorded with a Vitalograph, and measurements of dust concentration were performed before and after working shifts on three occasions at bog $A$ and once at bog B. Recordings were done both during the day and night shifts. The peat dust concentrations on the first two examined days at bog $\mathrm{A}$, at the beginning of the season, were judged to be representative of a dry period with a low to normal dust production with the peat somewhat humid. The third recording at bog $\mathrm{A}$ and the only recording at bog $B$ were on very dry and hot days with considerable production of peat dust. The reference subjects were investigated with lung function tests before bronchoscopy was performed.

\section{SYMPTOMS}

The subjects were interviewed and questioned about their health state before the peat harvesting season. Before and after workshifts questionnaires were issued concerning upper and lower airway symptoms, eye problems, and general health state (questionnaire available on request).

\section{BRONCHOSCOPY}

Flexible fibreoptic bronchoscopy and the processing of the lavage fluid and cells were carried out as previously outlined. ${ }^{7}$ Fibronectin concentration in BAL fluid was measured according to Blaschke et al 
Table 1 Data from dust sampling in breathing zone of peat workers during an 8-12 hour workshift. Amounts of total dust and the respirable part are expressed in $\mathrm{mg} /$ workshift. Sampling was done three times at Bog $A$ and once at Bog B. Figures in parentheses refer to one particularly heavily exposed subject

\begin{tabular}{|c|c|c|c|c|c|}
\hline & \multicolumn{3}{|c|}{$\operatorname{Bog} A(n=11)$} & \multicolumn{2}{|c|}{$\operatorname{Bog} B(n=6)$} \\
\hline $\begin{array}{l}\text { Respirable dust: } \\
\text { Median value } \\
\text { Range }\end{array}$ & $\begin{array}{l}<0.1 \\
<0.1-0.3\end{array}$ & $\begin{array}{l}<0.1 \\
<0.1-0.3\end{array}$ & $\begin{array}{l}<0.1 \\
<0.1-0.5\end{array}$ & 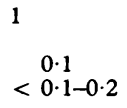 & $(2 \cdot 7)$ \\
\hline $\begin{array}{l}\text { Total dust: } \\
\text { Median value } \\
\text { Range }\end{array}$ & $\begin{array}{l}0.3 \\
0 \cdot 2-0.6\end{array}$ & $\begin{aligned} & 0.5 \\
< & 0.1-0.6\end{aligned}$ & $\begin{array}{l}1 \cdot 1 \\
0 \cdot 6-3 \cdot 2\end{array}$ & $\begin{array}{l}0 \cdot 4 \\
0 \cdot 2-0 \cdot 7\end{array}$ & $(19 \cdot 7)$ \\
\hline
\end{tabular}

and hyaluronan concentration was assessed according to principles previously described..$^{9-11}$ These substances were measured because of their association with airway inflammation and EAA. ${ }^{12}$

\section{STATISTICS}

The Spearman rank correlation coefficient test was used in calculations of correlation between variables. A p value $<0.05$ was considered significant. Wilcoxon's rank sum test was employed for comparison between groups regarding BAL parameters.

\section{Results}

\section{DUST MEASUREMENTS}

Dust concentrations were recorded with personal equipment during the 8-12 hour workshifts at three different times at bog $\mathrm{A}$ and once at bog $\mathrm{B}$ (table 1 ). Air humidity varied between $40-90 \%$ and the temperature varied between $9-18^{\circ} \mathrm{C}$. On average the workers were exposed to low total dust and respirable dust concentrations. The exposure dose varied considerably, however, among the peat workers, with some tractor drivers hardly exposed at all because they were inside vehicles equipped with dust filters. Some workers were moderately exposed, especially if part of their work had to be done out in the field. One bulldozer driver engaged in stockpiling, was forced to work with an open cabin door because of the heat and insufficient ventilation system. He was therefore exposed to much higher peat dust concentrations than any of the other peat workers (concentrations in parentheses in table 1).

\section{SYMPTOMS}

Two of the subjects scored mild eye symptoms and irritation of the throat that increased throughout the workshift. None of the subjects, including the two with asthma, scored breathlessness, wheezing, or other airway symptoms. No subject reported symptoms that may be connected with EAA or ODTS.

\section{LUNG FUNCTION}

All reference subjects had normal lung function. At the beginning of the peat harvesting season the lung function parameters of the peat workers, with the two asthmatic subjects excluded, expressed as mean (SD) in per cent of predicted values were; $\mathrm{FEV}_{1} 96 \%$ (SD 8; range 88-118\%), FVC $103 \%$ (SD 8; range 82$114 \%$ ), $\mathrm{FEF}_{25-75} 74 \%$ (SD 15; range $40-102 \%$ ), and $\%$ change in $\mathrm{N}_{2} / 1109 \%$ (range $65-204 \%$ ). All peat workers, with the exception of the smoking supervisor, had normal lung function. The supervisor had normal $\mathrm{FEV}_{1}, \mathrm{FVC}$, and $\%$ change in $\mathrm{N}_{2} / \mathrm{l}$, but an abnormal $\mathrm{FEF}_{25-75}(40 \%$ of normal value).

At the start of the season both asthmatic subjects were asymptomatic and had normal lung function. One of the subjects with asthma became gradually more obstructive during the season, with a total reduction of $\mathrm{FEV}_{1}$ to $66 \%$ of the initial value. The other asthmatic worker experienced a mild decrease of $\mathrm{FEV}_{1}$ to $91 \%$ of the initial value.

The figure shows the mean changes in lung function over workshifts and over season, with the asthmatic workers excluded. The changes were small and not statistically significant for the group as a whole.

The peat workers were not uniformly exposed to peat dust and a correlation was found between reduction in $\mathrm{FEV}_{1}$ and the respirable fraction of peat dust. When respirable dust concentrations of less than $0.1 \mathrm{mg} / \mathrm{m}^{3}$ air (the detection limit) were set to $0.1 \mathrm{mg} / \mathrm{m}^{3}$, Spearman's rank correlation coefficient
Over workshift

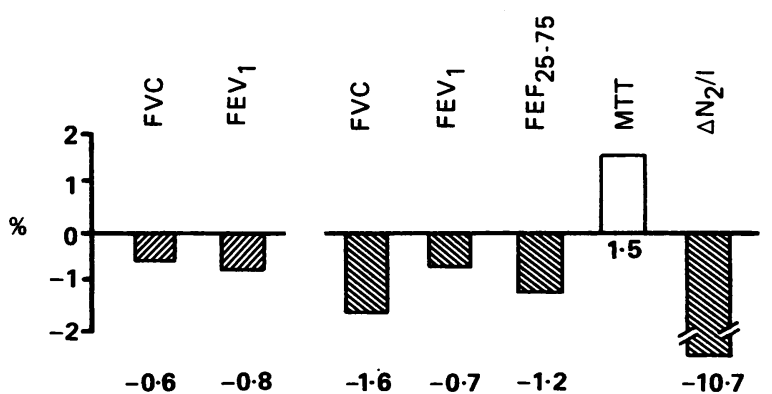

Mean changes of lung function over workshifts and over work season for 15 peat workers. Data are expressed as \% initial values. Data for the two asthmatic peat workers are not included. 
Table 2 Bronchoalveolar lavage characteristics for six peat workers and 13 reference subjects. Subject 4 was exposed to particularly high dust concentrations

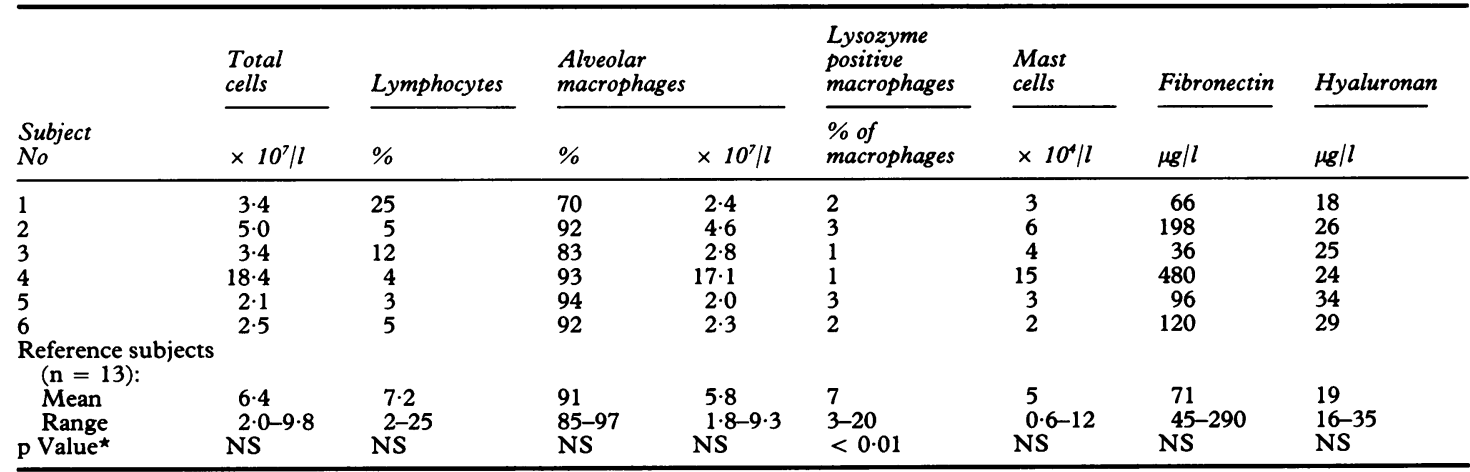

$\star$ Wilcoxon's rank sum test. NS = Non-significant.

was $-0.37(p<0.02)$. A lower but still significant $(p<0.05)$ coefficient of -0.32 was found when the respirable dust concentrations of less than $0.1 \mathrm{mg} / \mathrm{m}^{3}$ were calculated as $0 \mathrm{mg} / \mathrm{m}^{3}$. With the two asthmatic workers included the $p$ value was $<0.01$. The FVC was not correlated with either the respirable fraction or total dust concentrations when the asthmatic workers were excluded.

\section{BAL FLUID RESULTS}

The mean recovery of BAL fluid was $124 \mathrm{ml}(52 \%$, range $30-65 \%$ ) from the peat workers and $142 \mathrm{ml}$ $(60 \%$, range $45-70 \%)$ from the controls. Table 2 shows the differential cell counts. All peat workers had normal neutrophil and eosinophil cell numbers, but a significantly lower proportion of lysozyme positive macrophages, as a \% of all alveolar macrophages compared with the reference subjects $(p<$ 0.01 ). By using the peat workers' recordings of the respirable fraction of peat dust and setting the dust amounts to zero for the unexposed reference subjects, an inverse correlation between these two parameters was detected $(k=0.68, p<0.01)$.

Subject 4 , who was exposed to extremely high amounts of dust, had a pronounced increase in total cell numbers. This consisted almost entirely of alveolar macrophages. Among these only $1 \%$ stained positive for intracellular lysozyme, which is far below the normal range. The total mast cell number was high and the fibronectin concentration in BAL fluid for this subject was well above the upper range of the reference subjects. Hyaluronan concentration in BAL fluid was normal in all peat workers.

\section{Discussion}

The average dust concentrations recorded in the breathing zone of the peat workers were well below the TLV despite the excessive dust production during harvesting. This confirms the effectiveness of the air filters in the ventilated cabins of the vehicles. Direct comparison with earlier studies regarding dust exposure of the workers cannot be made, as dust concentrations were previously only recorded with stationary equipment in the fields. ${ }^{1-3}$ These earlier recordings showed dust concentrations many times greater than the TLV. Only a bulldozer driver in our study, described above and in table 1 (subject 4), was exposed to dust concentration compatible with those. As other workers occasionally had to do work outside their vehicles, some moderate exposure still occurred (table 1). The two asthmatic workers responded to the work situation with slightly increased airway obstruction, which was not unexpected. The exposure did not cause any deterioration in lung function for the study population as a unit, which accords with other studies. ${ }^{13}$

Because the workers were not uniformly exposed to peat dust and absence of changes in lung function in less exposed workers could mask effects in more exposed colleagues, correlations between exposure dose and lung effects were sought. A significant correlation was found between the respirable fraction of peat dust and decrease in $\mathrm{FEV}_{1}$ after a workshift. This response has not previously been reported. Although the effects on lung function were small the finding indicates that peat dust may act as a bronchoconstrictor even in healthy subjects.

Another indicator of the biological effects of peat dust was the evident reduction in lysozyme positive macrophages in BAL fluid, which significantly correlated with the exposure concentrations of respirable dust. This finding may well be part of a physiological response to the increased demands for alveolar macrophage clearance of dust particles in the air spaces. Lysozyme is known to be secreted during phagocytosis by macrophages. The reduced numbers of alveolar macrophages that stained positive for 
intracellular lysozyme are therefore believed to have been a consequence of the ingestion process of dust particles. Apart from this, no clear indications of ongoing inflammatory processes were found in the lungs of the workers, apart from the highly exposed bulldozer driver (subject 4 , table 2 ). He had an extremely high number of alveolar macrophages together with a fibronectin concentration far above the range of the reference subjects. Even though no definite conclusions can be made from findings in the one highly exposed worker, some speculations can be made. It seems feasible that the high number of alveolar macrophages is a result of the need for clearance of particles. Because fibronectin is known to be secreted by activated macrophages ${ }^{14}$ they may be the source of this protein, so frequently present in inflammatory processes. Other possible sources such as production by the bronchial epithelium after damage are also conceivable (Bjermer et al. Unpublished data). The high number of mast cells in this subject, despite absence of atopy or asthma, was probably an unspecific response to a noxious stimulus, as has previously been shown. ${ }^{71516}$ Finally it is important to note that the bronchoalveolar findings we present here do not in any substantial detail correspond with EAA or ODTS. ${ }^{12} 17$

It is concluded that peat workers using modern machines with air filtered ventilated cabins are exposed to low concentrations of peat dust. The respirable fraction of peat dust recorded in the breathing zone of the workers correlated significantly with a decrease in $\mathrm{FEV}_{1}$. The effect on lung function in non-asthmatic peat workers was, however, small. Analyses of BAL fluid showed a decrease in lysozyme positive alveolar macrophages in all examined peat workers, which correlated with the exposure to respirable dust. Furthermore, pronounced increases in alveolar macrophages, fibronectin concentration, and mast cells were found in one worker who was exposed to particularly high concentrations of dust.

The study was supported by The Swedish Heart and Lung Foundation.

Parts of the study have previously been presented in an abstract in the proceedings of an international workshop on "organic dusts and lung disease" held in Skokloster, Sweden, 24-27 October 1988.

Requests for reprints to: Thomas Sandström,
National Institute of Occupational Health, Medical Division, Box 6104, S-900 06 Umeå, Sweden.

1 Riihimaki, Pekkarinen M, Husman K, Kangas J, Itkonen A, Mattson $\mathrm{T}$, et al. Exposure to dust and its effects on the respiratory system in peat production. Proccedings 6th international peat congress. Duluth, Minnesota, 1981:317-20.

2 Kivekäs J, Husman K, Riihimäki H, Kangas J, Pekkarinen M. Exposure to peat dust, effects on peat bog workers' health. Symposium of IPS commissions I and II on socio-economic impacts of the utilization of peatlands in industry and forestry. Oulu, Finland, 1986

3 Cormier Y, Boulet L-P, Berube-Genest F. Effects of chronic organic dust exposure on respiratory function and airway responsiveness in peat moss factory workers. Arch Environ Health 1990;45:20-3.

4 Rylander R, Peterson Y, Donham KJ, eds. Health effects of organic dusts in the farm environment. Am J Ind Med 1986;10:1-340.

5 Rylander R, Peterson Y, eds. Organic dusts and lung disease. $\mathrm{Am}$ J Med 1990;17:1-149.

6 Bjermer L, Engström-Laurent A, Lundgren R, Rosenhall L, Hällgren R. Bronchoalveolar lavage mastocytosis in farmer's lung is related to disease activity. Arch Intern Med 1988; 295:1362-5.

7 Sandström T, Stjernberg N, Andersson M-C, KolmodinHedman B, Lundgren R, Rosenhall L, et al. Cell response in bronchoalveolar lavage fluid after exposure to sulfur dioxide. $A$ Time-Response study. Am Rev Respir Dis 1989;140:1828-31.

8 Blaschke E, Eklund A, Hernbrand R. Extracellular matrix components in bronchoalveolar lavage fluid in sarcoidosis and their relationship to signs in alveolitis. Am Rev Respir Dis 1990;4:1020-5.

9 Engström-Laurent A, Laurent UBG, Lilja K, Laurent TC. Concentration of sodium hyaluronate in serum. Scand J Clin Lab Invest 1985;45:497-504.

10 Hällgren R, Eklund A, Engström-Laurent A, Schmekel B. Hyaluronate in bronchoalveolar lavage fluid: a new marker in sarcoidosis reflecting pulmonary disease. $\mathrm{Br}$ Med $J$ 1985; 290:1778-81.

11 Laurent UBG, Tengblad A. Determination of hyaluronate in biological samples by a specific radioassay technique. Anal Biochem 1980;109:386-94.

12 Bjermer L, Engström-Laurent A, Lundgren R, Rosenhall L, Hällgren R. Hyaluronic acid and procollagen III peptide in bronchoalveolar lavage fluid as indicators of lung disease activity in farmer's lung. $B M J 1986 ; 295: 803-6$.

13 Blomqvist G, Bäckman G. Emmission av mikroorganismer i samband med brytning och hantering av torv. Umeà: Undersökningsrapport. Kemiska enheten, Arbetarskyddsstyrelsens forskningsavdelning, 1984:9. (In Swedish).

14 Perez T, Farre JM, Gosset P, Wallaert B, Duquesnoy B, Voisin $\mathrm{C}$, et al. Subclinical alveolar inflammation in rheumatoid arthritis: superoxide anion, neutrophil chemotactic activity and fibronectin generation by alveolar macrophages. European Respiratory Journal 1989;2:7-13.

15 Sandström T, Stjernberg N, Andersson M-C, KolmodinHedman B, Lindström K, Rosenhall L. Cell response in bronchoalveolar lavage fluid after sulfur dioxide exposure. Scand J Work Environ Health 1989;15:142-6.

16 Sandström T, Andersson M-C, Kolmodin-Hedman B, Stjernberg N, Ángström T. Bronchoalveolar mastocytosis and lymphocytosis after nitrogen dioxide exposure in man; a timekinetic study. European Respiratory Journal 1990;3:138-43.

17 Raymenants E, Demedts M, Nemery B. Bronchoalveolar lavage findings in a patient with organic dust toxic syndrome. Thorax 1990;45:713-4.

Accepted 8 April 1991 